\title{
Recent advances in understanding intestinal stem cell
}

\section{regulation [version 1; peer review: 3 approved]}

\author{
Deqing Hu(D1,2, Han Yan1, Xi C He³, Linheng Li3,4
}

\begin{abstract}
${ }^{1}$ Department of Cell Biology, 2011 Collaborative Innovation Center of Tianjin for Medical Epigenetics; Tianjin Key Laboratory of Medical Epigenetics, Tianjin Medical University, Heping, Tianjin, China

${ }^{2}$ Key Laboratory of Breast Cancer Prevention and Therapy, Ministry of Education, Tianjin's Clinical Research Center for Cancer, Tianjin Medical University Cancer Institute and Hospital, National Clinical Research Center for Cancer, Heping, Tianjin, China

${ }^{3}$ Stowers Institute for Medical Research, Kansas City, USA

${ }^{4}$ Department of Pathology \& Laboratory Medicine, University of Kansas Medical Center, Kansas City, China
\end{abstract}

V1 First published: 18 Jan 2019, 8(F1000 Faculty Rev):72

https://doi.org/10.12688/f1000research.16793.1

Latest published: 18 Jan 2019, 8(F1000 Faculty Rev):72

https://doi.org/10.12688/f1000research.16793.1

\section{Abstract}

Intestinal homeostasis and regeneration are driven by intestinal stem cells (ISCs) lying in the crypt. In addition to the actively cycling ISCS that maintain daily homeostasis, accumulating evidence supports the existence of other pools of stem/progenitor cells with the capacity to repair damaged tissue and facilitate rapid restoration of intestinal integrity after injuries. Appropriate control of ISCs and other populations of intestinal epithelial cells with stem cell activity is essential for intestinal homeostasis and regeneration while their deregulation is implicated in colorectal tumorigenesis. In this review, we will summarize the recent findings about ISC identity and cellular plasticity in intestine, discuss regulatory mechanisms that control ISCS for intestinal homeostasis and regeneration, and put a particular emphasis on extrinsic niche-derived signaling and intrinsic epigenetic regulation. Moreover, we highlight several fundamental questions about the precise mechanisms conferring robust capacity for intestine to maintain physiological homeostasis and repair injuries.

\section{Keywords}

Intestinal stem cell, Homeostasis, Regeneration, Plasticity,

Epigenetics, Nich

\section{Open Peer Review}

Approval Status

1

2

3

version 1

18 Jan 2019

Faculty Reviews are review articles written by the prestigious Members of Faculty Opinions. The articles are commissioned and peer reviewed before publication to ensure that the final, published version is comprehensive and accessible. The reviewers who approved the final version are listed with their names and affiliations.

1. Rongwen Xi, National Institute of Biological Sciences (NIBS), Beijing, China

2. Eduard Batlle, Institute for Research in Biomedicine (IRB Barcelona), The Barcelona Institute of Science and Technology,

Barcelona, Spain

3. Ramesh A Shivdasani, Dana-Farber Cancer Institute and Harvard Medical School, Boston, USA

Any comments on the article can be found at the 
end of the article.

Corresponding authors: Deqing Hu (hudq@tmu.edu.cn), Linheng Li (LIL@Stowers.org)

Author roles: Hu D: Conceptualization, Writing - Original Draft Preparation, Writing - Review \& Editing; Yan H: Writing - Review \& Editing; He XC: Writing - Review \& Editing; Li L: Conceptualization, Writing - Review \& Editing

Competing interests: No competing interests were disclosed.

Grant information: DH was supported by grants from the National Natural Science Foundation of China (31872825) and the Natural Science Foundation of Tianjin (18JCYBJC42400). Study in LL's lab was partially supported by National Institutes of Health grant U01DK085507, which is a collaborative research project of the Intestinal Stem Cell Consortium funded by the National Institute of Diabetes and Digestive and Kidney Diseases and the National Institute of Allergy and Infectious Diseases.

The funders had no role in study design, data collection and analysis, decision to publish, or preparation of the manuscript.

Copyright: $\odot 2019$ Hu D et al. This is an open access article distributed under the terms of the Creative Commons Attribution License, which permits unrestricted use, distribution, and reproduction in any medium, provided the original work is properly cited.

How to cite this article: Hu D, Yan H, He XC and Li L. Recent advances in understanding intestinal stem cell regulation [version 1; peer review: 3 approved] F1000Research 2019, 8(F1000 Faculty Rev):72 https://doi.org/10.12688/f1000research.16793.1

First published: 18 Jan 2019, 8(F1000 Faculty Rev):72 https://doi.org/10.12688/f1000research.16793.1 


\section{Introduction}

Intestinal epithelium is one of the fastest renewing tissues in mammals. Owing to the constant exposure of its luminal surface to injurious factors, such as pathogens and toxins, the average turnover rate is every three to five days in mice to replenish damaged cells ${ }^{1}$. These single-layered intestinal epithelial cells are organized into a crypt-villus structure and are predominantly composed of absorptive enterocytes and four secretory lineages known as enteroendocrine, Paneth, goblet, and tuft cells (Figure 1). The thin intestinal epithelial sheet is responsible for nutrient absorption and stool compaction and also serves as a front-line barrier against microorganisms and infections ${ }^{2}$. Maintenance and regeneration of this high-turnover tissue upon injury are fueled primarily by intestinal stem cells (ISCs) that reside at the bottom of the crypt, while differentiated absorptive and secretory cells are assembled as clusters or scattered along the crypt-villus axis ${ }^{3,4}$. More recently, considerable cellular plasticity was noted within intestine, and lineagerestricted progenitors or fully differentiated cells were able to replenish the tissue under certain conditions, such as DNA damage-induced injuries ${ }^{5-11}$.

ISCs possess both self-renewing capacity and multipotency to give rise to all types of intestinal epithelial cells. They divide and migrate upward to the middle region of the crypt to convert into transit-amplifying (TA) cells that divide rapidly for massive expansion before specializing into absorptive or secretory lineages ${ }^{4}$. Owing to the tremendous regenerative capacity and the simple anatomic structure, intestine and particularly its ISCs have become an elegant model system for studying homeostasis, regeneration, and oncogenic transformation of mammalian adult tissues ${ }^{12,13}$. Self-renewal and multipotency of ISCs and plasticity of intestinal epithelial cells are largely controlled by external signals emanated from neighboring niche cells and intrinsic molecular processes, including epigenetic regulation ${ }^{14,15}$. In support of a central role of extracellular niche factors, ISCs embedded in the crypt bottom are sustained by signals emanated from both epithelial and mesenchymal niches. In the in vitro 3D culture system, ISCs are able to self-organize into crypt-villus-like structures referred to as "organoids" (or precisely enteroids or colonoids if derived from small intestine or colon, respectively) in the presence of a defined set of growth factors ${ }^{16}$. These organoids comprise self-renewing ISCs intermingled with Paneth cells at the base of budding crypt and various differentiated lineages at blunt villus-like compartments and can be grown and maintained for many passages without losing normal karyotype over time ${ }^{17}$.

In this review, we summarize the latest advances in our understanding of ISC identity, cellular plasticity, the basis for intestinal homeostasis and regeneration as well as how ISC selfrenewal and multipotency are regulated, with a particular focus
Homeostasis

Physiological conditions

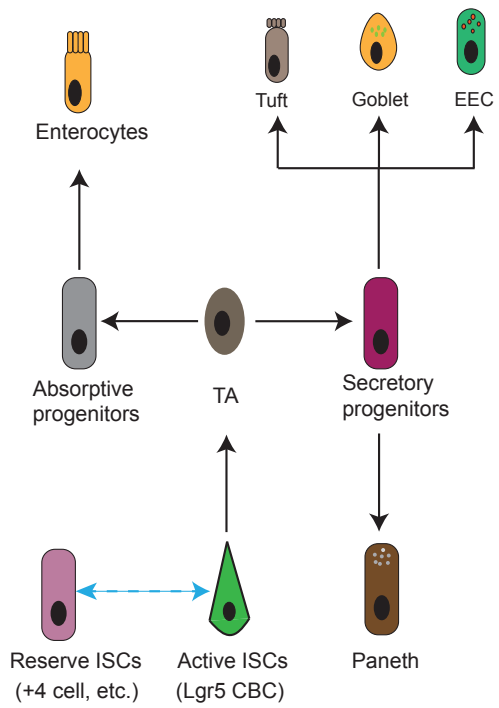

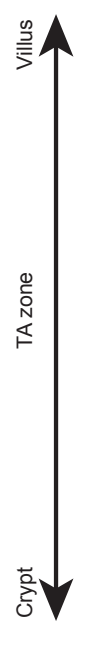

Pathophysiological conditions (irradiation, inflammation, etc)

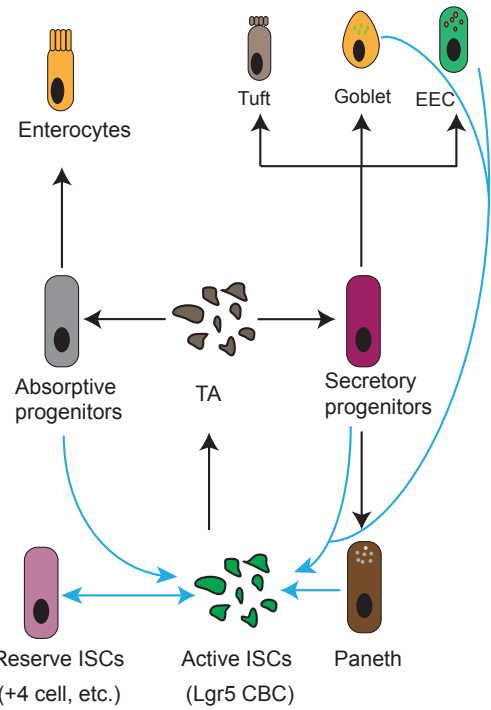

Figure 1. Hierarchy and plasticity of intestinal stem cells (ISCs). Under homeostatic conditions, active ISCs such as Lgr5 crypt base columnar cells (CBCs) migrate upwards to become transit-amplifying (TA) cells in the TA zone. TA cells divide rapidly and specify into either absorptive or secretory progenitors. Absorptive progenitors further differentiate into large quantities of enterocytes, while secretory progenitors commit to the Paneth, goblet, enteroendocrine (EEC), or goblet cells. Interconversion between reserve ISCs and active ISCs occurs occasionally in this setting (demonstrated by double-headed dash line). In response to radio- or chemo-therapies, the highly proliferative Lgr5 CBCs and TA cells are ablated. Reserve ISCs enter the cell cycle to replenish CBCs for subsequent regenerative process. Plasticity of differentiated progenies, including secretory and absorptive progenitors as well as terminally differentiated EEC and Paneth cells, has been observed when CBCs are damaged. These cells can revert to active ISCs and give rise to all intestinal cell types. However, whether they can bypass CBCs to transdifferentiate directly into other intestinal lineages and their functional importance to intestinal regeneration upon injuries remain to be determined. 
on extrinsic niche-derived signaling and intrinsically epigenetic regulation. Considering such progress in the mechanistic understanding of intestinal homeostasis and regeneration as well as the development of new models and techniques to faithfully mimic intestinal pathophysiology, we envision a variety of potent and effective therapeutic approaches for the treatment of intestinal diseases.

\section{Intestinal stem cells and cellular plasticity in intestine} For decades, crypts have been known as compartments comprising cellular sources for continuous intestinal homeostasis and robust post-injury regeneration ${ }^{18}$. However, the cellular basis and nature of ISCs that fuel the rapid renewal of intestine have been among the mysteries in the field of adult stem cell biology. It has long been assumed that mammalian tissue-resident adult stem cells, including ISCs, predominantly reside out of the cell cycle in a relatively quiescent $\mathrm{G}_{0}$ state so that genomic integrity can be sustained in response to genotoxic insults ${ }^{2,19}$. However, this prevailing notion has been amended by the identification of long-lived yet rapidly dividing intestinal crypt base columnar cells (CBCs) with relatively specific expression of $\operatorname{Lgr}^{20}$. They self-renew and are capable of differentiating into all types of intestinal epithelial cells in in vivo, as evidenced by lineage-tracing studies of in vivo and in vitro cultured organoids ${ }^{16,20,21}$. Owing to their mitotically active feature, Lgr5 CBCs were termed active ISCs and thought to sustain physiological homeostasis of the rapid renewing intestine $^{3}$. Intriguingly, a subset of epithelial cells residing specifically at +4 position relative to the base of crypts was observed to share some properties of tissue-resident adult stem cells, such as the ability of long-term DNA label retention and a strong resistance to stress, including chemotherapy and irradiation $^{19,22,23}$, and thus had been postulated to represent ISCs long before Lgr5 CBCs were identified.

Lgr5 CBCs are mitotically active and can regenerate whole intestinal epithelium under homeostatic conditions ${ }^{20}$. However, owing to their exquisite sensitivity to genotoxic stresses, Lgr5 $\mathrm{CBCs}$ are rapidly lost upon radio-/chemo-induced damage and thus could not account for the robust regenerative potential of post-injury intestine ${ }^{24}$. Moreover, studies with genetic ablation of Lgr5 CBCs by diphtheria toxin (DT) treatment of mice harboring Lgr5-driven DT receptor (DTR) allele revealed that these cells are dispensable for normal intestinal homeostasis, implying the existence of other epithelial cells with both stem cell activity and DNA damage-resistant capacity to replace Lgr5 $\mathrm{CBC}$ loss for intestinal regeneration ${ }^{25}$. Multiple populations of rare crypt cells marked by $\mathrm{Bmil}^{26}, \mathrm{Hopx}^{26}$, $\mathrm{mTert}^{27}$, Krt19 ${ }^{28}$, Lrig $1^{29}$, Sox $9^{30}, \operatorname{Mex} 3 \mathrm{a}^{31}$, or Prox $1^{6}$ have been found to reside at approximately +4 position by short-term CreER-activated cell fate mapping assay. In sharp contrast to Lgr5 CBCs, most cells labeled by these reporter alleles are slowly cycling and injuryresistant and can give rise to clonal lineage-tracing events albeit at much lower frequency than $\operatorname{Lgr} 5 \mathrm{CBCs}^{5}$. In light of the above features, these reporter-marked, predominantly +4 resident cells were defined as reserve ISCs in the literature ${ }^{3}$.

In contrast to their unique spatial localization noted in genetic-marked reporter assays, transcriptomic analyses revealed that endogenous Bmi1, mTert, and Hopx are broadly expressed throughout crypt cells, even in the active Lgr5 CBCs, reflecting a certain inconsistency between reporter activity and actual mRNA expression of the endogenous alleles ${ }^{32-34}$. Multiple reasons could underlie this discrepancy, such as (1) difference in the $3^{\prime}$ untranslated region (UTR) sequence between CreER reporter and endogenous alleles. A direct comparison between the mRNA level of CreER reporter and endogenous alleles among distinct populations of crypt cells could determine whether CreER reporter can faithfully recapitulate expression of its endogenous counterpart at transcriptional and post-transcriptional levels. (2) As activation of genetic reporters in lineage-tracing studies requires reaching a certain threshold of CreER activity, cells marked by genetic reporters following short-term tamoxifen administration may point to a stronger CreER activity in these cells than in other populations of crypt cells, which could result from differential levels of CreER protein or tamoxifen permeability in distinct types of crypt cells. Ideally, development of immunohistological grade antibodies that can specially recognize the endogenous protein of reported markers for ISCs will resolve these discrepancies and help determine their actual distribution pattern throughout crypts.

As reserve ISCs marked by $\mathrm{Bmi1}^{+}, \mathrm{Hopx}^{+}, \mathrm{mTert}$, Lrig1, and so on can give rise to all types of epithelial lineages, including the active Lgr5 CBCs in lineage-tracing studies, they have initially been posited to sit at the apex of the cellular hierarchy in intestine ${ }^{25,26}$. However, single- or bulk-cell transcriptomic profiling analyses have invariably detected the expression of a few enteroendocrine markers within reserve populations of ISCs, indicating some common features between reserve ISCs and committed enteroendocrine cells or hinting at a potential developmental plasticity of lineage-restricted secretory progenitors in intestine ${ }^{35}$. It should be mentioned that definition of reserve ISCs hinges solely on the functional criteria, including injury resistance, multipotency, cell cycle entry from $\mathrm{G}_{0}$ to $G_{1}$ upon damage, and long-term maintenance, all of which can be illustrated by Cre recombinase-induced lineage-tracing assays ${ }^{3,5}$. Cells marked with $\mathrm{Bmi1}^{+}$, $\mathrm{Hopx}^{+}$, mTert, and so on fulfill these functionally defining criteria and could act as bona fide reserve ISCs for tissue regeneration ${ }^{24,26,27,36}$. The fact that stem cells can express multiple-lineage genes in a fluctuating way, assumed as priming, has been reported in adult stem cells ${ }^{37}$ as well as in pluripotent embryonic stem cells, which express a significant level of representative genes for primordial germ cells in an undifferentiated pluripotent state ${ }^{38-40}$. Therefore, caution should be exercised when defining ISC identity simply on the basis of transcriptomic analysis. Nevertheless, more intense studies to further investigate the heterogeneity of +4 epithelial cells with single-cell high-throughput strategies are required to deepen our understanding of the identity of reserve stem cells in intestine.

Cellular plasticity has been observed in several mammalian tissues and could act as an additional mechanism for tissue regeneration ${ }^{41}$. Direct evidence showing developmental plasticity of enteroendocrine progenitors comes from lineage tracing of cells marked with Prox1, which is a transcription factor expressed predominantly in mature enteroendocrine cells and is essential for its commitment from ISCs ${ }^{6,42-45}$. Prox 1 enteroendocrine cells can function as reserve ISCs as they assume both homeostatic 
and injury-inducible stem activity in lineage-tracing reporter assays $^{6}$. Besides mature enteroendocrine cells, considerable plasticity and clonal lineage-tracing events have been noted in other progenies of Lgr5 CBCs, such as enteroendocrine progenitors marked by $\mathrm{Bmi}^{7}$, $\mathrm{Alpi}^{+}$absorptive progenitors ${ }^{8}$, secretory precursors expressing Atoh $1^{10}$ or $\mathrm{D}_{111^{11}}, \mathrm{CD} 9^{+} \mathrm{CD} 274^{+}$goblet precursor $^{7}$, fully differentiated Paneth cells ${ }^{46,47}$, and a small population of $\mathrm{Dclk}^{+}$tuft cells ${ }^{48}$ in certain situations, such as inflammation, radio-/chemo-induced intestinal injuries, or upon loss of Lgr5 CBCs by DT administration (Figure 1). However, the functional robustness and contribution of these lineagecommitted cells to intestinal homeostasis and restoration upon tissue damage remain unclear and will be worth future investigation. Furthermore, whether these differentiated epithelia can bypass Lgr5 CBCs and transdifferentiate directly into other epithelial lineages is also instrumental for understanding the mechanisms of regenerative process and awaits clarification in forthcoming studies. Another concern to be considered is that haploinsufficiency in the knocked-in allele used in current genetic tracing assays was recently reported to result in a misleading phenotype as seen in pancreatic systems ${ }^{49}$.

\section{Extrinsic niche regulation of intestinal stem cells}

The activity of ISCs is stringently controlled to ensure proper proliferation and differentiation. Tight regulation of ISCs is achieved primarily through extrinsic signaling molecules emanated from their surrounding cells that altogether constitute a unique niche microenvironment ${ }^{15,50}$. Recent intensive studies have led to gradual identification of vital niche components that include both epithelial progenies of ISCs and mesenchymal cells, such as Paneth cells, fibroblasts, immune cells, enteric neurons, and endothelial cells $\mathrm{s}^{51,52}$. When perturbed by injurious factors, these intestinal niche cells can be rewired for coordinated production of cytokines and growth factors to activate ISCs for rapid regeneration. To date, various niche factorderived signaling pathways have been identified to be essential for ISC activity, intestinal homeostasis, and regeneration. In this section, we will briefly summarize the central roles of Wnt, bone morphogenetic protein (BMP), Notch, epidermal growth factor (EGF), and Hippo signaling in ISC regulation.

In the Wnt pathway, binding of Wnt ligands to their Frizzled receptor on targeted cells induces collapse of cytoplasmic APC destruction complex and subsequent nuclear translocation of $\beta$-catenin to activate Wnt target genes through association with T-cell factor (TCF) transcription factors ${ }^{53}$. Wnt signaling is progressively reduced from crypt to villus axis and is indispensable for ISC maintenance and intestinal regeneration ${ }^{32,54,55}$. Its abrogation via inactivating Tcf1/2 mutation $^{56}$, Tef4 deletion ${ }^{57}$, or exogenous expression of Wnt inhibitor Dkk1 $1^{58,59}$ invariably leads to Lgr5 CBC loss and decreased crypt cell proliferation. Augmentation of activity of this pathway by Apc inactivating mutation, constitutive activating mutation in $\beta$-catenin, or simultaneous deletion of two E3 ligases (Rnf43 and Znrf3) targeting Wnt ligand receptors for degradation unanimously result in crypt expansion and rapid appearance of intestinal adenomas in mice ${ }^{60-64}$. Although the functional importance of Wnt signaling and its contribution to intestinal regulation have been well appreciated ${ }^{55}$, the cellular source for Wnt ligands remains incompletely understood. Various types of niche cells have been found to express a significant level of Wnt ligands, such as small intestinal Paneth cells ${ }^{51}$, colonic Reg4 ${ }^{+65}$ or cKit $^{+66}$ secretory cells, and numerous subsets of stromal cells $\mathrm{s}^{67,68}$. Although epithelial Wnts can promote expansion of Lgr5 CBCs during in vitro organoid culture, their ablation does not demonstrate a notable impact on crypt cell proliferation and intestinal homeostasis in vivo, suggesting a significant redundancy of cellular origin of Wnt ligands in sustaining intestinal integrity ${ }^{67-70}$. In line with this assumption, recent studies found that Foxl1 ${ }^{+71,72}$,

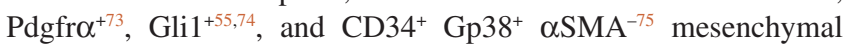
cells serve as major sources of Wnt activity and play pivotal roles in sustaining intestinal homeostasis in vivo. Abolition of Wnt secretion in Foxl1 ${ }^{+}$, Gli1 ${ }^{+}$, or $\mathrm{Pdgfr}^{+}$cells by genetic excision of porcupine (Porcn) impairs proliferation of Lgr5 CBCs and leads to corruption of intestinal integrity ${ }^{71,73,74}$. Whether these mesenchymal cells with distinct markers overlap with each other to some extent or even represent the same subsets of non-epithelial cells is currently unclear. Moreover, how Wnt activity in these mesenchymal cells is regulated in response to intestinal injuries, such as inflammation and chemo-/radiotoxicity, remains unanswered. Future investigations combining genetic approaches with single-cell RNA-sequencing technology will address these critical questions.

BMP signaling assumes an increasing gradient along the intestinal crypt-villus axis and serves as a critical inducer for ISC differentiation, thereby playing a vital role in balancing the effect of Wnt signaling on intestinal homeostasis ${ }^{76,77}$. BMPs belong to the transforming growth factor-beta superfamily of ligands and can induce phosphorylation of cytoplasmic R-Smads (Smad1/5/8) through binding to the membrane-embedded serine/threonine kinase type I and II receptors. Phosphorylated R-Smads form a complex with Co-Smad (Smad4) and subsequently enter the nucleus, where they regulate expression of targeted genes through association with a variety of co-factors ${ }^{78,79}$. The initial experimental evidence implicating an inhibitory role of BMP signaling in ISC self-renewal comes from conditional deletion of BMP receptor Bmprla and transgenic expression of BMP antagonist Noggin in mice, both of which unanimously lead to development of multiple polyposis in small intestine ${ }^{80-82}$. Similarly, aberrant expression of BMP antagonist Gremlin1 was noted in patients with hereditary mixed polyposis syndrome and its transgenic expression in mice leads to the appearance of ectopic crypts and subsequent oncogenic transformation ${ }^{83,84}$. Gene expression and in situ hybridization analyses demonstrated that BMP ligands and BMP antagonists are produced primarily by mesenchymes residing at different regions of the crypt-villus unit. BMP2 and BMP4 are secreted by intravillus and intercrypt mesenchymal cells, whereas Noggin, Gremlin1, Gremlin2, and chordin-like 1 antagonists are expressed by cryptal myofibroblasts and smooth muscle cells beneath the crypt bottom ${ }^{80,85}$. To date, little is known about the role and cellular source of other BMP ligands in intestine and whether ablation of these niche cells has an impact on intestinal integrity and tumorigenesis. Future studies are needed to address questions in this regard.

Notch receptors are single-pass type I transmembrane heterodimer proteins that comprise functional extracellular truncation, 
transmembrane, and intracellular (NICD) domain. Activation of Notch receptors begins with their binding to Notch ligands presented on an adjacent cell, which leads to cytoplasmic proteolytic cleavage of Notch receptors by $\gamma$-secretase complex and subsequent nuclear translocation of intracellular NICD to regulate transcription of target genes ${ }^{86}$. Notch signaling has been shown to contribute to Lgr5 CBC maintenance and proliferation $^{87-89}$ and its inhibition skews intestinal differentiation toward goblet lineage ${ }^{90-92}$. Paneth cells express and present Notch ligands Dll1 and Dll4 to adjacent Lgr5 CBCs to facilitate their self-renewal ${ }^{51}$. Moreover, activation of Notch signaling in Paneth cells by forced expression of NICD can result in acquisition of a stem-like property in these cells ${ }^{46}$. Notch signaling is also involved in controlling secretory and absorptive lineage determination when $\mathrm{CBCs}$ start to differentiate. Its activation stimulates Hes1 expression for transcriptional silencing of Atoh1, a master transcription factor for secretory lineage determination, thereby blocking secretory differentiation but promoting enterocyte specification of Notch receptor activated cells $^{93}$. Expression of Notch ligand Dll1 on secretory cells prevents a secretory fate of neighboring cells but drives these cells toward absorptive lineage through Notch signaling activation, which is a biological event referred to as lateral inhibition $^{88}$. Although Notch signaling contributes to CBC proliferation and intestinal homeostasis, the role of niche cells expressing Notch ligands remains unclear.

The Hippo pathway functions as a vital regulator of tissue homeostasis and organ size and its deregulation is implicated in the development of multiple types of cancer in humans. In the presence of extracellular stimuli, transcriptional activator YAP/TAZ complex is phosphorylated by upstream serinethreonine kinase MST1/MST2/Sav1-LATS1/2/MOB1A/B cascade, leading to either cytoplasmic sequestration or proteasomal degradation of YAP/TAZ. Without Hippo activation, non-phosphorylated YAP/TAZ enters the nucleus and acts as a co-activator for the TEAD transcription factor to regulate expression of genes associated with cell growth and proliferation ${ }^{94,95}$. The Hippo pathway is constitutively active in intestine under homeostatic conditions and its genetic inactivation via transgenic expression of YAP/TAZ or conditional deletion of Sav1, an upstream negative regulator of YAP, increases ISC proliferation and leads to crypt hyperplasia ${ }^{96,97}$. Hippo signaling is also indispensable for intestinal regeneration in mouse models of dextran sodium sulfate (DSS)-induced colitis and radiation-induced injury ${ }^{97,98}$. Transgenic expression of YAP induces an EGF signaling-dependent regenerative program to facilitate intestinal regeneration ${ }^{98}$. Appropriate activation of Wnt signaling is essential for intestinal recovery following injury. However, its aberrant activation could lead to oncogenic transformation or reduce ISC survival through increasing radio-sensitivity of ISCs to DNA damage during intestinal regeneration ${ }^{99}$. In addition to the transcriptional regulatory activity of nuclear YAP/TAP complex, unphosphorylated cytoplasmic complexes are integral components of $\beta$-catenin destruction complex and thus play a critical role in restricting Wnt signaling activity ${ }^{100}$. Paradoxically, it has been noted that conditional deletion of YAP in intestinal epithelia augments Wnt activity and causes crypt hyperplasia and overgrowth throughout small intestine and colon after radiation-induced injury ${ }^{101}$. These findings suggest that the Hippo pathway has dual roles in regulating both Wnt and Egf signaling and its impact on intestinal regeneration is contextdependent and could be determined by net activity of these two pathways. More work is needed to deepen our understanding of the molecular mechanisms that control the balanced activation of Wnt and Egf pathways by Hippo signaling during intestinal regeneration.

EGF communicates with target cells through the EGF receptor, which is a member of the ErbB family of tyrosine receptor kinases ${ }^{102}$. Paneth cells express EGF and sustain proliferation of Lgr5 CBCs through its receptor ErbB ${ }^{103}$. EGF supplementation of culture medium dramatically increases the efficiency of organoid formation in vitro ${ }^{17}$. Lrig1 is a negative feedback regulator of ErbB receptor and its ablation causes crypt expansion in mice ${ }^{29,104}$. Although these findings support a crucial role of EGF signaling in $\mathrm{CBC}$ proliferation, the additional cellular source of EGF growth factor except for Paneth cells in intestine remains ambiguous.

\section{Intrinsically epigenetic regulation of intestinal stem cells}

Intestinal homeostasis and regeneration are accompanied by drastic transcriptional alterations that are achieved through the cooperation between extrinsic niche signaling-controlled transcription factors/co-activators and intrinsic epigenetic regulators. Epigenetics refers to the inherited alteration in gene expression and phenotype that occur without changes in DNA sequence. It consists primarily of DNA methylation, histone modification, and chromatin remodeling ${ }^{105,106}$. In contrast to the extensively studied extrinsic niche factors, the role of intrinsically epigenetic mechanisms in intestinal homeostasis and regeneration is poorly understood. In this section, we will briefly discuss the currently limited knowledge of epigenetic mechanisms in intestinal regulation.

With the tremendous advancements in fluorescence-activated cell sorting, identification of lineage-specific markers, and nextgeneration sequencing technology, epigenetic characterization of distinct types of intestinal epithelial cells has recently become feasible. Initial studies with DNase I mapping for accessible chromatin regions and $\mathrm{H} 3 \mathrm{~K} 4 \mathrm{me} 2$ and $\mathrm{H} 3 \mathrm{~K} 27 \mathrm{ac}$ ChIP-seq (chromatin immunoprecipitation sequencing) for active enhancers showed that ISCs and enterocyte and secretory progenitors assume remarkable similarity in distribution pattern of open chromatin elements and active enhancers throughout the genome $^{107}$. However, these observations are not in line with the subsequent studies that employ assay for transposaseaccessible chromatin using sequencing (ATAC-seq) to profile open chromatin regions among ISCs and enterocyte and secretory progenitors. The latter studies identified thousands of unique open chromatin regions among these populations and found that accessible chromatin states in secretory progenitors shift to resemble ISCs during dedifferentiation upon injuries (Figure 2) ${ }^{7}$. Although the discrepancy between the two studies can be explained by cellular heterogeneity and the different sensitivity of technologies employed, the functional importance of those unique open chromatin elements in secretory lineage 


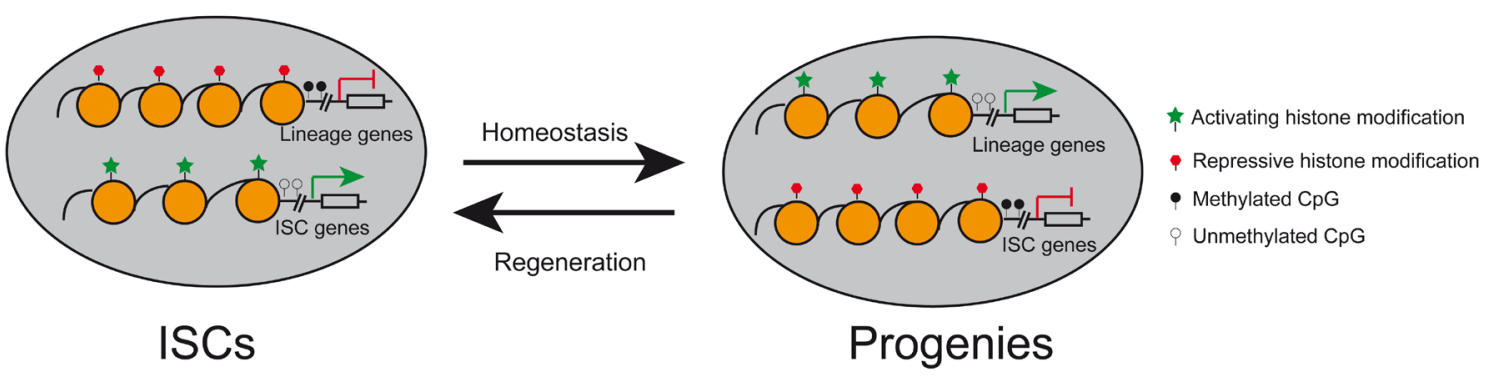

Figure 2. Epigenetic reprogramming for intestinal homeostasis and regeneration. During homeostasis, intestinal stem cells (ISCs) adopt a unique epigenetic signature and chromatin accessibility that collaboratively lead to expression of ISC-related genes and shutdown of lineage-specific factors. Lineage specification of ISCs is accompanied by epigenetic remodeling and chromatin accessibility changes that turn off ISCs genes while activating lineage-restricted genes. During the regenerative process, epigenetic landscape and chromatin accessibility are reconfigured to resemble ISCs during dedifferentiation of ISC progenies.

specification, dedifferentiation, and regeneration has not been determined experimentally. In addition, comprehensive profiling of distinct histone modifications in purer populations of intestinal lineages will determine whether the epigenetic landscape varies during intestinal homeostasis and regeneration.

Initial bisulfite-sequencing of ISCs and their differentiated progenies in villus revealed minimal dynamics of DNA methylome during intestinal differentiation ${ }^{108}$. This study used a cutoff of a minimal differential methylation of $40 \%$ to identify differentially methylated regions (DMRs) between ISCs and villous cells. As the distal regulatory regions are low-methylated at an overall methylation level of $30 \%$ in intestinal cells and display average change of about $15 \%$ in DNA methylation during intestinal differentiation, the cutoff criteria of analysis used in the study eliminates the identification of DMRs during differentiation of ISCs $^{108,109}$. Subsequent bisulfite-sequencing studies with distinct analytic standards identified many DMRs at enhancers and disclosed a tight correlation between the DMRs and transcriptional alterations between two populations of cells, implying that the DNA methylation may have a vital role in intestinal renewal ${ }^{110}$. This viewpoint has been proven by genetic ablation of Dnmt1 and Tet1 in intestine, which are maintenance methyltransferase and hydroxylase for DNA methylation, respectively ${ }^{106}$. Dnmt1 is essential for intestinal development in newborn mice as inducible deletion of Dnmtl at perinatal stage causes genomic instability, premature differentiation, apoptosis, loss of villi, and decreased proliferation of crypt cells ${ }^{111,112}$. The essential role of DNA methylation for intestinal development is also reflected in Tet1-deleted mice. Tet1-null mice exhibit retarded growth, shorter intestines, weaker capability to form in vitro organoids, and reduced postnatal viability ${ }^{113}$. Acute ablation of Dnmtl in adult intestinal epithelia causes a slight expansion of the proliferative crypt zone. However the crypt morphology recovers and DNA methylation restores to normal level several days after Dnmt1 deficiency. A subsequent study revealed that de novo methyltransferase Dnmt3b can compensate for Dnmt1 loss to maintain intestinal integrity as ablation of both enzymes leads to genome demethylation, genomic instability, increased apoptosis, and decreased survival ${ }^{114}$. Taken together, these pieces of genetic evidence strongly support that dynamic regulation of DNA methylation acts as an essential epigenetic mechanism underlying intestinal development and homeostasis.

Post-translational modification of histones, such as methylation and ubiquitination, constitutes an additional component of epigenetic mechanism in transcriptional regulation, embryonic development, and adult tissue homeostasis ${ }^{115}$. Monoubiquitination of lysine 119 on H2A (H2A119 mUb) and methylation of lysine 27 on $\mathrm{H} 3$ (H3K27me) correlate with transcriptional repression and are implemented by polycomb repressive complex 1 (PRC1) and polycomb repressive complex 2 (PRC2), respectively ${ }^{116}$. The activity of PRC1 and PRC2 stems from Ring1a/1b E3 ligase and Ezh1/2 methyltransferases and has been shown to be essential for normal intestinal homeostasis or regeneration following injuries. Loss of function of the total PRC1 activity via Ring 1 a/b double deletion in intestinal epithelia compromises ISC self-renewal and intestinal integrity and results in morbidity through de-repression of a number of transcription factors that negatively regulate $\mathrm{Wnt}$ signaling ${ }^{117}$.

Loss of PRC2 activity via $\mathrm{Ah}^{\text {Cre }}$ or VillinCreER-induced epithelial deletion of the Eed, a scaffold protein of the complex, leads to a clear defect in cell proliferation in crypts, a marked increase in the number of goblet cells, mislocalized Paneth cells, and compromised regenerative capacity ${ }^{118-120}$. The homeostatic and regenerative defect of intestine in the absence of PRC2 results at least in part from aberrant upregulation of Cdkn2a and some master regulators for secretory lineages that are bivalently marked, normally targeted, and repressed by this complex ${ }^{118}$. Conditional ablation of catalytic subunit of PRC2 complex Ezh2 does not show any abnormalities in the intestinal homeostasis, indicating that the other H3K27 methyltransferase Ezh1 could compensate for Ezh2 loss to maintain intestinal integrity ${ }^{120}$. Further studies are needed to know the role and target genes of individual non-canonic PRC1 and PRC2 complexes in intestinal renewal and regeneration.

\section{Conclusions and future perspectives}

Over the past decade, remarkable progress has been made in our understanding of intestinal biology. It has become evident that active Lgr5 CBCs and reserve ISCs work in a coordinated 
manner to maintain intestinal homeostasis and replenish the tissue upon injuries. In addition, differentiated epithelial cells possess considerable plasticity and can dedifferentiate to ISCs for intestinal regeneration in mouse models when active $\mathrm{CBCs}$ are damaged or artificially removed. Many niche-derived factors and a few epigenetic regulators have been identified and characterized for their roles in intestinal morphogenesis, homeostasis, and regeneration. Despite these considerable advances in recent years, several fundamental questions remain to be addressed about the precise molecular mechanisms controlling self-renewal, lineage commitment, and plasticity of ISCs. First, the cellular source of distinct environmental factors crucial for ISC function and the role of immune cells, peripheral nerve cells, and other ISC-proximal cells remain poorly understood; thus, extensive studies of these niche components will offer more insight into the extrinsic regulatory mechanisms for ISC function. Second, comprehensive characterization of the epigenetic landscape of various intestinal cells coupled with conditional ablation of key chromatin regulators in murine models will help determine the molecular basis underlying the remarkable plasticity of intestine in response to injuries. Third, the physiological function and contribution of differentiated crypt cells to radio-/chemoinduced intestinal regeneration remain to be experimentally evaluated. Fourth, the molecular mechanisms that reserve ISCs and differentiated crypt cells use to sense and replenish lost $\mathrm{CBCs}$ are largely unexplored; future investigation in this regard will help design effective therapeutic approaches to facilitate intestinal recovery after damage. Lastly, does aging-associated loss of regenerative potential of ISCs result from alterations in niche factors or epigenetic regulation or both ${ }^{121-123}$ ? The more we understand the above fundamental questions, the better we can employ ISCs for regenerative medicine.

\section{Grant information}

DH was supported by grants from the National Natural Science Foundation of China (31872825) and the Natural Science Foundation of Tianjin (18JCYBJC42400). Study in LL's lab was partially supported by National Institutes of Health grant U01DK085507, which is a collaborative research project of the Intestinal Stem Cell Consortium funded by the National Institute of Diabetes and Digestive and Kidney Diseases and the National Institute of Allergy and Infectious Diseases.

The funders had no role in study design, data collection and analysis, decision to publish, or preparation of the manuscript.

\section{Acknowledgments}

We are grateful to Karen Tannen (Stowers Institute for Medical Research, Kansas City, MO, 64110, USA) for proofreading and editing. We apologize to colleagues whose studies were not cited in this review due to space limitations.
1. $\quad F$ Beumer J, Clevers $\mathrm{H}$ : Regulation and plasticity of intestinal stem cells during homeostasis and regeneration. Development. 2016; 143(20): 3639-49. PubMed Abstract | Publisher Full Text | F1000 Recommendation

2. Clevers $\mathrm{H}$ : The intestinal crypt, a prototype stem cell compartment. Cell. 2013; 154(2): 274-84.

PubMed Abstract | Publisher Full Text

3. $\mathrm{Li}$ L, Clevers $\mathrm{H}$ : Coexistence of quiescent and active adult stem cells in mammals. Science. 2010; 327(5965): 542-5.

PubMed Abstract | Publisher Full Text | Free Full Text

4. Barker N, van de Wetering M, Clevers H: The intestinal stem cell. Genes Dev. 2008; 22(14): 1856-64.

PubMed Abstract | Publisher Full Text | Free Full Text

5. Yousefi M, Li L, Lengner CJ: Hierarchy and Plasticity in the Intestinal Stem Cell Compartment. Trends Cell Biol. 2017; 27(10): 753-64. PubMed Abstract | Publisher Full Text | Free Full Text

6. Yan KS, Gevaert O, Zheng GXY, et al:: Intestinal Enteroendocrine Lineage Cells Possess Homeostatic and Injury-Inducible Stem Cell Activity. Cell Stem Cell. 2017; 21(1): 78-90.e6.

PubMed Abstract | Publisher Full Text | Free Full Text

7. F Jadhav U, Saxena M, O'Neill NK, et al:: Dynamic Reorganization of Chromatin Accessibility Signatures during Dedifferentiation of Secretory Precursors into Lgr5+ Intestinal Stem Cells. Cell Stem Cell. 2017; 21(1): 65-77.e5. PubMed Abstract | Publisher Full Text | Free Full Text | F1000 Recommendation

8. F Tetteh PW, Basak O, Farin HF, et al.: Replacement of Lost Lgr5-Positive Stem Cells through Plasticity of Their Enterocyte-Lineage Daughters. Cell Stem Cell. 2016; 18(2): 203-13.

PubMed Abstract | Publisher Full Text | F1000 Recommendation

9. $\mathrm{F}$ Ishibashi $\mathrm{F}$, Shimizu H, Nakata T, et al:: Contribution of ATOH1+ Cells to the Homeostasis, Repair, and Tumorigenesis of the Colonic Epithelium. Stem Cell Reports. 2018; 10(1): 27-42.

PubMed Abstract | Publisher Full Text | Free Full Text | F1000 Recommendation

10. F Tomic G, Morrissey E, Kozar S, et al:: Phospho-regulation of ATOH1 Is Required for Plasticity of Secretory Progenitors and Tissue Regeneration. Cell
Stem Cell. 2018; 23(3): 436-443.e7.

PubMed Abstract | Publisher Full Text | Free Full Text | F1000 Recommendation

11. $\mathrm{F}$ van $\mathrm{Es} \mathrm{JH}$, Sato $\mathrm{T}$, van de Wetering $\mathrm{M}$, et al.: DII1+ secretory progenitor cells revert to stem cells upon crypt damage. Nat Cell Biol. 2012; 14(10): 1099-104. PubMed Abstract | Publisher Full Text | Free Full Text | F1000 Recommendation

12. Potten CS, Booth C, Hargreaves D: The small intestine as a model for evaluating adult tissue stem cell drug targets. Cell Prolif. 2003; 36(3): 115-29. PubMed Abstract | Publisher Full Text

13. Wang F, Scoville D, He XC, et al.: Isolation and characterization of intestinal stem cells based on surface marker combinations and colony-formation assay. Gastroenterology. 2013; 145(2): 383-395.e21. PubMed Abstract | Publisher Full Text | Free Full Text

14. $\mathrm{F}$ Roostaee A, Benoit YD, Boudjadi S, et al.: Epigenetics in Intestinal Epithelial Cell Renewal. J Cell Physiol. 2016; 231(11): 2361-7.

PubMed Abstract | Publisher Full Text | Free Full Text | F1000 Recommendation

15. Sailaja BS, He XC, Li L: The regulatory niche of intestinal stem cells. J Physiol. 2016; 594(17): 4827-36.

PubMed Abstract | Publisher Full Text | Free Full Text

16. F Sato T, Vries RG, Snippert HJ, et al:: Single Lgr5 stem cells build crypt-villus structures in vitro without a mesenchymal niche. Nature. 2009; 459(7244): 262-5. PubMed Abstract | Publisher Full Text | F1000 Recommendation

17. Sato $\mathrm{T}$, Clevers $\mathrm{H}$ : Growing self-organizing mini-guts from a single intestinal stem cell: mechanism and applications. Science. 2013; 340(6137): 1190-4. PubMed Abstract | Publisher Full Text

18. Bjerknes $\mathrm{M}$, Cheng $\mathrm{H}$ : Intestinal epithelial stem cells and progenitors. Methods Enzymol. 2006; 419:337-383.

PubMed Abstract | Publisher Full Text

19. Potten CS, Kovacs L, Hamilton E: Continuous labelling studies on mouse skin and intestine. Cell Prolif. 1974; 7(3): 271-83. Publisher Full Text

20. $\mathrm{F}$ Barker $\mathrm{N}$, van Es $\mathrm{JH}$, Kuipers J, et al:: Identification of stem cells in smal intestine and colon by marker gene Lgr5. Nature. 2007; 449(7165): 1003-7. PubMed Abstract | Publisher Full Text | F1000 Recommendation 
21. Barker $\mathrm{N}$, van Es $\mathrm{JH}$, Jaks $\mathrm{V}$, et al:: Very long-term self-renewal of small intestine, colon, and hair follicles from cycling Lgr5 $5^{\text {tve }}$ stem cells. Cold Spring Harb Symp Quant Biol. 2008; 73: 351-6.

PubMed Abstract | Publisher Full Text

22. Potten CS, Owen G, Booth D: Intestinal stem cells protect their genome by selective segregation of template DNA strands. J Cell Sci. 2002; 115(Pt 11): $2381-8$

PubMed Abstract

23. Potten CS: Extreme sensitivity of some intestinal crypt cells to $X$ and gamma irradiation. Nature. 1977; 269(5628): 518-21. PubMed Abstract | Publisher Full Text

24. F Yan KS, Chia LA, Li X, et al:: The intestinal stem cell markers Bmi1 and Lgr5 identify two functionally distinct populations. Proc Natl Acad Sci U S A. 2012; 109(2): 466-71.

PubMed Abstract | Publisher Full Text | Free Full Text | F1000 Recommendation

25. $\mathrm{F}$ Tian $\mathrm{H}$, Biehs $\mathrm{B}$, Warming $\mathrm{S}$, et al: A reserve stem cell population in small intestine renders Lgr5-positive cells dispensable. Nature. 2011; 478(7368) 255-9.

PubMed Abstract | Publisher Full Text | Free Full Text | F1000 Recommendation

26. F Takeda N, Jain R, LeBoeuf MR, et al:: Interconversion between intestinal stem cell populations in distinct niches. Science. 2011; 334(6061): 1420-4. PubMed Abstract | Publisher Full Text | Free Full Text | F1000 Recommendation

27. F Montgomery RK, Carlone DL, Richmond CA, et al:: Mouse telomerase reverse transcriptase (mTert) expression marks slowly cycling intestinal stem cells. Proc Natl Acad Sci U S A. 2011; 108(1): 179-84.

PubMed Abstract | Publisher Full Text | Free Full Text | F1000 Recommendation

28. Asfaha S, Hayakawa Y, Muley A, et al.: Krt19+/Lgr5- Cells Are Radioresistant Cancer-Initiating Stem Cells in the Colon and Intestine. Cell Stem Cell. 2015; 16(6): $627-38$.

PubMed Abstract | Publisher Full Text | Free Full Text

29. $\mathrm{F}$ Powell AE, Wang $\mathrm{Y}$, Li $\mathrm{Y}$, et al.: The pan-ErbB negative regulator Lrig1 is an intestinal stem cell marker that functions as a tumor suppressor. Cell. 2012; 149(1): 146-58.

PubMed Abstract | Publisher Full Text | Free Full Text | F1000 Recommendation

30. Roche $\mathrm{KC}$, Gracz $\mathrm{AD}$, Liu XF, et al:: SOX9 maintains reserve stem cells and preserves radioresistance in mouse small intestine. Gastroenterology. 2015; 149(6): 1553-1563.e10.

PubMed Abstract | Publisher Full Text | Free Full Text

31. F Barriga FM, Montagni E, Mana M, et al:: Mex3a Marks a Slowly Dividing Subpopulation of Lgr5+ Intestinal Stem Cells. Cell Stem Cell. 2017; 20(6): 801-816.e7.

PubMed Abstract | Publisher Full Text | Free Full Text | F1000 Recommendation

32. Muñoz J, Stange DE, Schepers AG, et al:: The Lgr5 intestinal stem cell signature: robust expression of proposed quiescent ' +4 ' cell markers. $E M B O \mathrm{~J}$. 2012; 31(14): 3079-91.

PubMed Abstract | Publisher Full Text | Free Full Text

33. Itzkovitz S, Lyubimova A, Blat IC, et al:: Single-molecule transcript counting of stem-cell markers in the mouse intestine. Nat Cell Biol. 2011; 14(1): 106-14. PubMed Abstract | Publisher Full Text | Free Full Text

34. Li N, Yousefi M, Nakauka-Ddamba A, et al:: Single-cell analysis of proxy reporter allele-marked epithelial cells establishes intestinal stem cell hierarchy. Stem Cell Reports. 2014; 3(5): 876-91.

PubMed Abstract | Publisher Full Text | Free Full Text

35. F Buczacki SJ, Zecchini HI, Nicholson AM, et al:: Intestinal label-retaining cells are secretory precursors expressing Lgr5. Nature. 2013; 495(7439): 65-9. PubMed Abstract | Publisher Full Text | F1000 Recommendation

36. Sangiorgi E, Capecchi MR: Bmi1 is expressed in vivo in intestinal stem cells. Nat Genet. 2008; 40(7): 915-20.

PubMed Abstract | Publisher Full Text | Free Full Text

37. F Akashi K, $\mathrm{He} X, \mathrm{Chen} \mathrm{J}$, et al.: Transcriptional accessibility for genes of multiple tissues and hematopoietic lineages is hierarchically controlled during early hematopoiesis. Blood. 2003; 101(2): 383-9.

PubMed Abstract | Publisher Full Text | F1000 Recommendation

38. Yamaji M, Ueda J, Hayashi K, et al:: PRDM14 ensures naive pluripotency through dual regulation of signaling and epigenetic pathways in mouse embryonic stem cells. Cell Stem Cell. 2013; 12(3): 368-82. PubMed Abstract | Publisher Full Text

39. Bao S, Leitch HG, Gillich A, et al:: The germ cell determinant Blimp1 is not required for derivation of pluripotent stem cells. Cell Stem Cell. 2012; 11(1): $110-7$.

PubMed Abstract | Publisher Full Text | Free Full Text

40. F Chu LF, Surani MA, Jaenisch R, et al.: Blimp1 expression predicts embryonic stem cell development in vitro. Curr Biol. 2011; 21(20): 1759-65. PubMed Abstract | Publisher Full Text | Free Full Text | F1000 Recommendation

41. Tetteh PW, Farin HF, Clevers H: Plasticity within stem cell hierarchies in mammalian epithelia. Trends Cell Biol. 2015; 25(2): 100-8.

PubMed Abstract | Publisher Full Text

42. Petrova TV, Nykänen A, Norrmén C, et al:: Transcription factor PROX1 induces colon cancer progression by promoting the transition from benign to highly dysplastic phenotype. Cancer Cell. 2008; 13(5): 407-19.

PubMed Abstract | Publisher Full Text
43. Egerod KL, Engelstoft MS, Grunddal KV, et al:: A major lineage of enteroendocrine cells coexpress CCK, secretin, GIP, GLP-1, PYY, and neurotensin but not somatostatin. Endocrinology. 2012; 153(12): 5782-95. PubMed Abstract | Publisher Full Text

44. Engelstoft MS, Egerod KL, Lund ML, et al.: Enteroendocrine cell types revisited. Curr Opin Pharmacol. 2013: 13(6): 912-21. PubMed Abstract | Publisher Full Text

45. Habib AM, Richards P, Cairns LS, et al:: Overlap of endocrine hormone expression in the mouse intestine revealed by transcriptional profiling and flow cytometry. Endocrinology. 2012; 153(7): 3054-65. PubMed Abstract | Publisher Full Text | Free Full Text

46. F Yu S, Tong K, Zhao Y, et al:: Paneth Cell Multipotency Induced by Notch Activation following Injury. Cell Stem Cell. 2018; 23(1): 46-59.e5. PubMed Abstract | Publisher Full Text | Free Full Text | F1000 Recommendation

47. F Schmitt M, Schewe M, Sacchetti A, et al:: Paneth Cells Respond to Inflammation and Contribute to Tissue Regeneration by Acquiring Stem-like Features through SCF/c-Kit Signaling. Cell Rep. 2018; 24(9): 2312-2328.e7. PubMed Abstract | Publisher Full Text | F1000 Recommendation

48. Westphalen $\mathrm{CB}$, Asfaha S, Hayakawa $Y$, et al:: Long-lived intestinal tuft cells serve as colon cancer-initiating cells. J Clin Invest. 2014; 124(3): 1283-95. PubMled Abstract | Publisher Full Text | Free Full Text

49. F Shen J, Ha DP, Zhu G, et al:: GRP78 haploinsufficiency suppresses acinar-to-ductal metaplasia, signaling, and mutant Kras -driven pancreatic tumorigenesis in mice. Proc Natl Acad Sci. 2017; 114: E4020-E4029. Publisher Full Text |F1000 Recommendation

50. F Chacón-Martínez CA, Koester J, Wickström SA: Signaling in the stem cell niche: regulating cell fate, function and plasticity. Development. 2018; 145(15): pii: dev165399.

PubMed Abstract | Publisher Full Text | F1000 Recommendation

51. F Sato $\mathrm{T}$, van $\mathrm{Es} \mathrm{JH}$, Snippert $\mathrm{HJ}$, et al:: Paneth cells constitute the niche for Lgr5 stem cells in intestinal crypts. Nature. 2011; 469(7330): 415-8. PubMed Abstract | Publisher Full Text | Free Full Text | F1000 Recommendation

52. F Roulis M, Flavell RA: Fibroblasts and myofibroblasts of the intestinal lamina propria in physiology and disease. Differentiation. 2016; 92(3): 116-31. PubMed Abstract | Publisher Full Text | F1000 Recommendation

53. Clevers H, Nusse R: Wnt/ $\beta$-catenin signaling and disease. Cell. 2012; 149(6): 1192-205.

PubMed Abstract | Publisher Full Text

54. Batlle E, Henderson JT, Beghtel $\mathrm{H}$, et al.: Beta-catenin and TCF mediate cell positioning in the intestinal epithelium by controlling the expression of EphB/ ephrinB. Cell. 2002; 111(2): 251-63. PubMed Abstract | Publisher Full Text

55. F Valenta T, Degirmenci B, Moor AE, et al.: Wnt Ligands Secreted by Subepithelial Mesenchymal Cells Are Essential for the Survival of Intestina Stem Cells and Gut Homeostasis. Cell Rep. 2016; 15(5): 911-8. PubMed Abstract | Publisher Full Text | F1000 Recommendation

56. Korinek $\mathrm{V}$, Barker N, Willert $\mathrm{K}$, et al:: Two members of the Tcf family implicated in $\mathrm{Wnt} /$ beta-catenin signaling during embryogenesis in the mouse. Mol Cell Biol. 1998; 18(3): 1248-56.

PubMed Abstract | Publisher Full Text | Free Full Tex

57. $\mathrm{F}$ van Es JH, Haegebarth A, Kujala $\mathrm{P}$, et al.: A critical role for the Wnt effecto Tcf4 in adult intestinal homeostatic self-renewal. Mol Cell Biol. 2012; 32(10): 1918-27.

PubMed Abstract | Publisher Full Text | Free Full Text | F1000 Recommendation

58. Kuhnert F, Davis $\mathrm{CR}$, Wang $\mathrm{HT}$, et al:: Essential requirement for Wnt signaling in proliferation of adult small intestine and colon revealed by adenoviral expression of Dickkopf-1. Proc Natl Acad Sci U S A. 2004; 101(1): 266-71. PubMed Abstract | Publisher Full Text | Free Full Text

59. F Pinto D, Gregorieff A, Begthel $\mathrm{H}$, et al:: Canonical Wnt signals are essential for homeostasis of the intestinal epithelium. Genes Dev. 2003; 17(14): 1709-13. PubMed Abstract | Publisher Full Text | Free Full Text | F1000 Recommendation

60. $\mathrm{F}$ Koo BK, Spit M, Jordens I, et al:: Tumour suppressor RNF43 is a stem-cell E3 ligase that induces endocytosis of Wnt receptors. Nature. 2012; 488(7413): 665-9.

PubMed Abstract | Publisher Full Text | F1000 Recommendation

61. $\mathrm{F}$ Hao $\mathrm{HX}, \mathrm{Xie} \mathrm{Y}$, Zhang $\mathrm{Y}$, et al.: ZNRF3 promotes Wnt receptor turnover in an R-spondin-sensitive manner. Nature. 2012; 485(7397): 195-200. PubMed Abstract | Publisher Full Text | F1000 Recommendation

62. F Jiang $\mathrm{X}$, Charlat $\mathrm{O}$, Zamponi $\mathrm{R}$, et al.: Dishevelled promotes Wnt receptor degradation through recruitment of ZNRF3/RNF43 E3 ubiquitin ligases. Mol Cell. 2015; 58(3): 522-33.

PubMed Abstract | Publisher Full Text | F1000 Recommendation

63. Korinek V, Barker N, Morin PJ, et al:: Constitutive transcriptional activation by a beta-catenin-Tcf complex in APC ${ }^{-1}$ colon carcinoma. Science. 1997; 275(5307) $1784-7$.

PubMed Abstract | Publisher Full Text

64. Morin PJ, Sparks AB, Korinek V, et al.: Activation of beta-catenin-Tcf signaling in colon cancer by mutations in beta-catenin or APC. Science. 1997; 275(5307): 1787-90.

PubMed Abstract | Publisher Full Text 
65. F Sasaki N, Sachs N, Wiebrands K, et al:: Reg4+ deep crypt secretory cells function as epithelial niche for Lgr5+ stem cells in colon. Proc Natl Acad Sci U S A. 2016; 113(37): E5399-407.

PubMed Abstract | Publisher Full Text | Free Full Text | F1000 Recommendation

66. $\mathrm{F}$ Rothenberg ME, Nusse $\mathrm{Y}$, Kalisky $\mathrm{T}$, et al:: Identification of a cKit ${ }^{+}$ colonic crypt base secretory cell that supports $\mathrm{Lgr5}^{+}$stem cells in mice. Gastroenterology. 2012; 142(5): 1195-1205.e6.

PubMed Abstract | Publisher Full Text | Free Full Text | F1000 Recommendation

67. Farin $\mathrm{HF}$, van $\mathrm{Es} \mathrm{JH}$, Clevers $\mathrm{H}$ : Redundant sources of Wnt regulate intestinal stem cells and promote formation of Paneth cells. Gastroenterology. 2012; 143(6): 1518-1529.e7.

PubMed Abstract | Publisher Full Text

68. Kabiri Z, Greicius G, Madan B, et al:: Stroma provides an intestinal stem cell niche in the absence of epithelial Wnts. Development. 2014; 141(11): 2206-15. PubMed Abstract | Publisher Full Text

69. Durand A, Donahue B, Peignon G, et al: Functional intestinal stem cells after Paneth cell ablation induced by the loss of transcription factor Math1 (Atoh1) Proc Natl Acad Sci U S A. 2012; 109(23): 8965-70.

PubMed Abstract | Publisher Full Text | Free Full Text

70. San Roman AK, Jayewickreme CD, Murtaugh LC, et al: Wnt secretion from epithelial cells and subepithelial myofibroblasts is not required in the mouse intestinal stem cell niche in vivo. Stem Cell Reports. 2014; 2(2): 127-34. PubMed Abstract | Publisher Full Text | Free Full Text

71. F Shoshkes-Carmel M, Wang YJ, Wangensteen KJ, et al:: Subepithelial telocytes are an important source of Wnts that supports intestinal crypts. Nature. 2018; 557(7704): 242-6.

PubMed Abstract | Publisher Full Text | Free Full Text | F1000 Recommendation

72. F Aoki R, Shoshkes-Carmel M, Gao N, et al.: Foxl1-expressing mesenchymal cells constitute the intestinal stem cell niche. Cell Mol Gastroenterol Hepatol. 2016; 2(2): 175-88

PubMed Abstract | Publisher Full Text | Free Full Text | F1000 Recommendation

73. F Greicius G, Kabiri Z, Sigmundsson K, et al:: PDGFRa' pericryptal stromal cells are the critical source of Wnts and RSPO3 for murine intestinal stem cells in vivo. Proc Natl Acad Sci U S A. 2018; 115(14): E3173-E3181.

PubMed Abstract | Publisher Full Text | Free Full Text | F1000 Recommendation

74. F Degirmenci B, Valenta T, Dimitrieva S, et al:: GLI1-expressing mesenchymal cells form the essential Wnt-secreting niche for colon stem cells. Nature. 2018 558(7710): 449-53.

PubMed Abstract | Publisher Full Text | F1000 Recommendation

75. F Stzepourginski I, Nigro G, Jacob JM, et al:: CD34+ mesenchymal cells are a major component of the intestinal stem cells niche at homeostasis and after injury. Proc Natl Acad Sci U S A. 2017; 114(4): E506-E513.

PubMed Abstract | Publisher Full Text | Free Full Text | F1000 Recommendation

76. Hardwick JCH, van den Brink GR, Bleuming SA, et al:: Bone morphogenetic protein $\mathbf{2}$ is expressed by, and acts upon, mature epithelial cells in the colon. Gastroenterology. 2004; 126(1): 111-21.

PubMed Abstract | Publisher Full Tex

77. F Qi Z, Li Y, Zhao B, et al:: BMP restricts stemness of intestinal Lgr5+ stem cells by directly suppressing their signature genes. Nat Commun. $2017 ; 8$ : 13824 .

PubMed Abstract | Publisher Full Text | Free Full Text | F1000 Recommendation

78. David CJ, Massagué J: Contextual determinants of TGF $\beta$ action in development, immunity and cancer. Nat Rev Mol Cell Biol. 2018; 19(7): 419-35. PubMed Abstract | Publisher Full Text

79. Feng $\mathrm{XH}$, Derynck R: Specificity and versatility in tgf-beta signaling through Smads. Annu Rev Cell Dev Biol. 2005; 21: 659-93. PubMed Abstract | Publisher Full Text

80. He XC, Zhang J, Tong WG, et al:: BMP signaling inhibits intestinal stem cell self-renewal through suppression of Wnt-beta-catenin signaling. Nat Genet. 2004; 36(10): 1117-21.

PubMed Abstract | Publisher Full Text

81. Haramis AP, Begthel H, van den Born M, et al:: De novo crypt formation and juvenile polyposis on BMP inhibition in mouse intestine. Science. 2004 303(5664): 1684-6.

PubMed Abstract | Publisher Full Text

82. Batts LE, Polk DB, Dubois RN, et al.: Bmp signaling is required for intestinal growth and morphogenesis. Dev Dyn. 2006; 235(6): 1563-70. PubMed Abstract | Publisher Full Text

83. Davis H, Irshad S, Bansal M, et al:: Aberrant epithelial GREM1 expression initiates colonic tumorigenesis from cells outside the stem cell niche. Nat Med. 2015; 21(1): 62-70.

PubMed Abstract | Publisher Full Text | Free Full Text

84. F Jaeger E, Leedham S, Lewis A, et al:: Hereditary mixed polyposis syndrome is caused by a $40-\mathrm{kb}$ upstream duplication that leads to increased and ectopic expression of the BMP antagonist GREM1. Nat Genet. 2012; 44(6): 699-703. PubMed Abstract | Publisher Full Text | Free Full Text | F1000 Recommendation

85. Kosinski C, Li VS, Chan AS, et al.: Gene expression patterns of human colon tops and basal crypts and BMP antagonists as intestinal stem cell niche factors. Proc Natl Acad Sci U S A. 2007; 104(39): 15418-23.

PubMed Abstract | Publisher Full Text | Free Full Text
86. Kopan R, Ilagan MX: The canonical Notch signaling pathway: unfolding the activation mechanism. Cell. 2009; 137(2): 216-33.

PubMed Abstract | Publisher Full Text | Free Full Text

87. Pellegrinet L, Rodilla V, Liu Z, et al.: DII1- and dll4-mediated notch signaling are required for homeostasis of intestinal stem cells. Gastroenterology. 2011; 140(4): 1230-1240.e1-7.

PubMed Abstract | Publisher Full Text | Free Full Text

88. VanDussen KL, Carulli AJ, Keeley TM, et al:: Notch signaling modulates proliferation and differentiation of intestinal crypt base columnar stem cells. Development. 2012; 139(3): 488-97.

PubMed Abstract | Publisher Full Text | Free Full Text

89. Tian H, Biehs B, Chiu C, et al:: Opposing activities of Notch and Wnt signaling regulate intestinal stem cells and gut homeostasis. Cell Rep. 2015; 11(1): 33-42.

PubMed Abstract | Publisher Full Text | Free Full Text

90. Milano J, McKay J, Dagenais C, et al.: Modulation of notch processing by gamma-secretase inhibitors causes intestinal goblet cell metaplasia and induction of genes known to specify gut secretory lineage differentiation. Toxicol Sci. 2004; 82(1): 341-58

PubMed Abstract | Publisher Full Text

91. F van Es JH, van Gijn ME, Riccio O, et al:: Notch/gamma-secretase inhibition turns proliferative cells in intestinal crypts and adenomas into goblet cells. Nature. 2005; 435(7044): 959-63.

PubMed Abstract | Publisher Full Text | F1000 Recommendation

92. van Es $\mathrm{JH}$, de Geest $\mathrm{N}$, van de Born M, et al:: Intestinal stem cells lacking the Math1 tumour suppressor are refractory to Notch inhibitors. Nat Commun. 2010; 1(1): 18

PubMed Abstract | Publisher Full Text | Free Full Text

93. Ueo T, Imayoshi I, Kobayashi T, et al:: The role of Hes genes in intestinal development, homeostasis and tumor formation. Development. 2012; 139(6): 1071-82.

PubMed Abstract | Publisher Full Text

94. F Fu V, Plouffe SW, Guan KL: The Hippo pathway in organ development, homeostasis, and regeneration. Curr Opin Cell Biol. 2017; 49: 99-107. PubMed Abstract | Publisher Full Text | F1000 Recommendation

95. Pan D: The hippo signaling pathway in development and cancer. Dev Cell. 2010; 19(4): 491-505.

PubMed Abstract | Publisher Full Text | Free Full Text

96. Imajo M, Ebisuya M, Nishida E: Dual role of YAP and TAZ in renewal of the intestinal epithelium. Nat Cell Biol. 2015; 17(1): 7-19. PubMed Abstract | Publisher Full Text

97. Cai J, Zhang $\mathrm{N}$, Zheng $\mathrm{Y}$, et al.: The Hippo signaling pathway restricts the oncogenic potential of an intestinal regeneration program. Genes Dev. 2010; 24(21): 2383-8.

PubMed Abstract | Publisher Full Text | Free Full Text

98. F Gregorieff A, Liu Y, Inanlou MR, et al.: Yap-dependent reprogramming of Lgr5+ stem cells drives intestinal regeneration and cancer. Nature. 2015; 526(7575): 715-8.

PubMed Abstract | Publisher Full Text | F1000 Recommendation

99. Tao $\mathrm{S}$, Tang $\mathrm{D}$, Morita $\mathrm{Y}$, et al:: Wnt activity and basal niche position sensitize intestinal stem and progenitor cells to DNA damage. EMBO J. 2015; 34(5): 624-40.

PubMed Abstract | Publisher Full Text | Free Full Text

100. F Azzolin L, Panciera T, Soligo S, et al.: YAP/TAZ incorporation in the $\beta$-catenin destruction complex orchestrates the Wnt response. Cell. 2014; 158(1): 157-70. PubMed Abstract | Publisher Full Text | F1000 Recommendation

101. F Barry ER, Morikawa T, Butler BL, et al.: Restriction of intestinal stem cell expansion and the regenerative response by YAP. Nature. 2013; 493(7430): $106-10$.

PubMed Abstract | Publisher Full Text | Free Full Text | F1000 Recommendation

102. Roskoski R Jr: The ErbB/HER family of protein-tyrosine kinases and cancer. Pharmacol Res. 2014; 79: 34-74. PubMed Abstract | Publisher Full Text

103. Schepers $\mathrm{A}$, Clevers $\mathrm{H}$ : Wnt signaling, stem cells, and cancer of the gastrointestinal tract. Cold Spring Harb Perspect Biol. 2012; 4(4): a007989. PubMed Abstract | Publisher Full Text | Free Full Text

104. Wong VW, Stange DE, Page ME, et al.: Lrig1 controls intestinal stem-cell homeostasis by negative regulation of ErbB signalling. Nat Cell Biol. 2012; 14(4): 401-8.

PubMed Abstract | Publisher Full Text | Free Full Text

105. $\mathrm{F}$ Allis $\mathrm{CD}$, Jenuwein $\mathrm{T}$ : The molecular hallmarks of epigenetic control. Nat Rev Genet 2016; 17(8): 487-500.

PubMed Abstract | Publisher Full Text | F1000 Recommendation

106. Hu D, Shilatifard A: Epigenetics of hematopoiesis and hematological malignancies. Genes Dev. 2016; 30(18): 2021-41. PubMed Abstract | Publisher Full Text | Free Full Text

107. F Kim TH, Li F, Ferreiro-Neira I, et al.: Broadly permissive intestinal chromatin underlies lateral inhibition and cell plasticity. Nature. 2014; 506(7489): 511-5. PubMed Abstract | Publisher Full Text | Free Full Text | F1000 Recommendation

108. Kaaij $L T$, van de Wetering $M$, Fang $F$, et al.: DNA methylation dynamics during 
intestinal stem cell differentiation reveals enhancers driving gene expression in the villus. Genome Biol. 2013; 14(5): R50.

PubMed Abstract | Publisher Full Text | Free Full Text

109. F Stadler MB, Murr R, Burger L, et al:: DNA-binding factors shape the mouse methylome at distal regulatory regions. Nature. 2011; 480(7378): 490-5. PubMed Abstract | Publisher Full Text | F1000 Recommendation

110. Sheaffer KL, Kim R, Aoki R, et al:: DNA methylation is required for the control of stem cell differentiation in the small intestine. Genes Dev. 2014; 28(6): 652-64. PubMed Abstract | Publisher Full Text | Free Full Text

111. Elliott EN, Sheaffer KL, Schug J, et al.: Dnmt1 is essential to maintain progenitors in the perinatal intestinal epithelium. Development. 2015; 142(12): 2163-72.

PubMed Abstract | Publisher Full Text | Free Full Text

112. Yu DH, Gadkari M, Zhou Q, et al:: Postnatal epigenetic regulation of intestinal stem cells requires DNA methylation and is guided by the microbiome. Genome Biol. 2015; 16: 211.

PubMed Abstract | Publisher Full Text | Free Full Text

113. $\mathrm{F}$ Kim R, Sheaffer KL, Choi I, et al:: Epigenetic regulation of intestinal stem cells by Tet1-mediated DNA hydroxymethylation. Genes Dev. 2016; 30(21): 2433-42.

PubMed Abstract | Publisher Full Text | Free Full Text | F1000 Recommendation

114. F Elliott EN, Sheaffer KL, Kaestner KH: The 'de novo' DNA methyltransferase Dnmt3b compensates the Dnmt1-deficient intestinal epithelium. eLife. 2016; 5: pii: e12975.

PubMed Abstract | Publisher Full Text | Free Full Text | F1000 Recommendation

115. Shilatifard A: The COMPASS family of histone H3K4 methylases: mechanisms of regulation in development and disease pathogenesis. Annu Rev Biochem. 2012; 81: 65-95.

PubMed Abstract | Publisher Full Text | Free Full Text
116. Margueron R, Reinberg D: The Polycomb complex PRC2 and its mark in life. Nature. 2011; 469(7330): 343-9.

PubMed Abstract | Publisher Full Text | Free Full Text

117. F Chiacchiera F, Rossi A, Jammula S, et al:: Polycomb Complex PRC1 Preserves Intestinal Stem Cell Identity by Sustaining Wnt/ $\beta$-Catenin Transcriptional Activity. Cell Stem Cell. 2016; 18(1): 91-103. PubMed Abstract | Publisher Full Text | F1000 Recommendation

118. F Chiacchiera F, Rossi A, Jammula S, et al:: PRC2 preserves intestinal progenitors and restricts secretory lineage commitment. EMBO J. 2016; 35(21): $2301-14$

PubMed Abstract | Publisher Full Text | Free Full Text | F1000 Recommendation

119. F Jadhav U, Nalapareddy K, Saxena M, et al:: Acquired Tissue-Specific Promoter Bivalency Is a Basis for PRC2 Necessity in Adult Cells. Cell. 2016 165(6): 1389-400

PubMed Abstract | Publisher Full Text | Free Full Text | F1000 Recommendation

120. F Koppens MA, Bounova G, Gargiulo G, et al:: Deletion of Polycomb Repressive Complex 2 From Mouse Intestine Causes Loss of Stem Cells. Gastroenterology. 2016; 151(4): 684-697.e12.

PubMed Abstract | Publisher Full Text | F1000 Recommendation

121. $\mathrm{F}$ Mihaylova $\mathrm{MM}$, Cheng $\mathrm{CW}, \mathrm{Cao} \mathrm{AQ}$, et al.: Fasting Activates Fatty Acid Oxidation to Enhance Intestinal Stem Cell Function during Homeostasis and Aging. Cell Stem Cell. 2018; 22(5): 769-778.e4.

PubMed Abstract | Publisher Full Text | Free Full Text | F1000 Recommendation

122. Potten CS, Martin K, Kirkwood TB: Ageing of murine small intestinal stem cells. Novartis Found Symp. 2001; 235: 66-79; discussion 79-84, 101-4. PubMed Abstract | Publisher Full Text

123. F Nalapareddy K, Nattamai KJ, Kumar RS, et al:: Canonical Wnt Signaling Ameliorates Aging of Intestinal Stem Cells. Cell Rep. 2017; 18(11): 2608-21. PubMed Abstract | Publisher Full Text | Free Full Text | F1000 Recommendation 


\section{Open Peer Review}

\section{Current Peer Review Status:}

\section{Editorial Note on the Review Process}

Faculty Reviews are review articles written by the prestigious Members of Faculty Opinions. The articles are commissioned and peer reviewed before publication to ensure that the final, published version is comprehensive and accessible. The reviewers who approved the final version are listed with their names and affiliations.

\section{The reviewers who approved this article are:}

\section{Version 1}

\section{Ramesh A Shivdasani}

Department of Medicine, Dana-Farber Cancer Institute and Harvard Medical School, Boston, USA Competing Interests: No competing interests were disclosed.

\section{Eduard Batlle} Institute for Research in Biomedicine (IRB Barcelona), The Barcelona Institute of Science and Technology, Barcelona, Spain

Competing Interests: No competing interests were disclosed.

\section{Rongwen Xi}

National Institute of Biological Sciences (NIBS), Beijing, China

Competing Interests: No competing interests were disclosed.

The benefits of publishing with F1000Research:

- Your article is published within days, with no editorial bias

- You can publish traditional articles, null/negative results, case reports, data notes and more

- The peer review process is transparent and collaborative

- Your article is indexed in PubMed after passing peer review

- Dedicated customer support at every stage

For pre-submission enquiries, contact research@f1000.com 